\title{
Increased Circulating and Urinary Levels of Soluble TAM Receptors in Diabetic Nephropathy
}

Peter Ochodnicky, ${ }^{*}$ Lionel Lattenist, ${ }^{*}$ Mohamed Ahdi, ${ }^{~}$ Jesper Kers, ${ }^{*}$ Melissa Uil, ${ }^{*}$ Nike Claessen, ${ }^{*}$ Jaklien C. Leemans, ${ }^{*}$ Sandrine Florquin, ${ }^{*}$ Joost C.M. Meijers, ${ }^{\delta \uparrow}$ Victor E.A. Gerdes, ${ }^{\dagger \S}$ and Joris J.T.H. Roelofs*

From the Departments of Pathology* and Experimental Vascular Medicine, ${ }^{\S}$ Academic Medical Center, University of Amsterdam, Amsterdam; the Department of Internal Medicine, ${ }^{\dagger}$ Slotervaart Hospital, Amsterdam; the Department of Plasma Proteins, ${ }^{\circledR}$ Sanquin Research, Amsterdam; and the Department of Pathology, ${ }^{\ddagger}$ Radboud University Nijmegen Medical Center, Nijmegen, the Netherlands

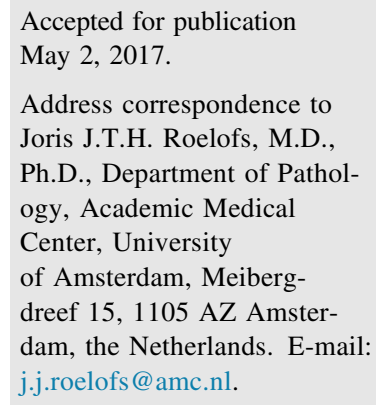

\begin{abstract}
TAM receptors (Tyro3, Axl, and Mer) have been implicated in innate immunity. Circulating TAM receptor soluble forms (sTyro3, sAxl, sMer) are related to autoimmune disorders. We investigated TAM and their ligand protein $S$ in patients with diabetes. Urinary and plasma levels of protein S, sTyro3, sAxl, and sMer were determined in 126 patients with diabetes assigned to a normoalbuminuric or macroalbuminuric (urinary albumin excretion $<30 \mathrm{mg} / 24$ hours and $>300 \mathrm{mg} / 24$ hours, respectively) study group and 18 healthy volunteers. TAM and protein $S$ immunostaining was performed on kidney biopsy specimens from patients with diabetic nephropathy $(n=9)$ and controls $(n=6)$. TAM expression and shedding by tubular epithelial cells were investigated by PCR and enzyme-linked immunosorbent assay in an in vitro diabetes model. Patients with macroalbuminuria diabetes had higher circulating levels of sMer and more urinary sTyro3 and sMer than normoalbuminuric diabetics. Increased clearance of sTyro3 and sMer was associated with loss of tubular Tyro3 and Mer expression in diabetic nephropathy tissue and glomerular depositions of protein S. During in vitro diabetes, human kidney cells had down-regulation of Tyro3 and Mer mRNA and increased shedding of sTyro3 and sMer. Renal injury in diabetes is associated with elevated systemic and urine levels of sMer and sTyro3. This is the first study reporting excretion of sTAM receptors in urine, identifying the kidney as a source of sTAM. (Am J Pathol 2017, 187: 1971-1983; http://dx.doi.org/10.1016/j.ajpath.2017.05.004)
\end{abstract}

Diabetic nephropathy (DN) is the leading cause of chronic kidney disease, reported in up to $45 \%$ of end-stage renal disease. ${ }^{1,2}$ Despite significant progress in understanding the DN pathophysiology, the complex sequence of events leading to glomerular and tubular damage is far from clear, and current treatment strategies still provide inadequate renoprotection. Therefore, identification of novel mediators of disease and potential therapeutic targets is warranted to reduce the enormous health and economic burden of DN.

Glomerular injury associated with an alteration of glomerular filtration barrier and development of microalbuminuria attributable to podocyte and endothelial dysfunction constitute key early pathologic features of DN. ${ }^{3-5}$ These events are followed by the development of overt proteinuria, glomerulosclerosis, and tubulointerstitial injury, leading eventually to nephron loss and renal function decline. ${ }^{6,7}$ Although diabetes mellitus has been traditionally viewed as a nonimmune disease, emerging evidence suggests that activation of innate immune mechanisms plays an important role in the development of diabetic renal injury. ${ }^{8,9}$ Infiltration of inflammatory monocytes or macrophages and subsequent cytokine release are prominent features of $\mathrm{DN}^{10,11}$ and are promoted by a proadhesive and proinflammatory phenotype of dysfunctional diabetic endothelium. Identification and characterization of novel mediators

Supported by the Dutch Kidney Foundation grants C09.2287 and KJPB 10.017 (J.J.T.H.R.), the Foundation for Clinical Research in Slotervaart Hospital (V.E.A.G.), and the Netherlands Organisation for Scientific Research grants 91712386 (J.C.L.) and 90713480 (J.J.T.H.R.).

Disclosures: None declared. 
involved in the regulation of renal inflammation might improve our understanding of DN pathology.

Tyrosine kinase receptors of the TAM family, including the three subtypes Tyro3, Axl, and Mer, have recently emerged as novel crucial regulators of innate immunity. ${ }^{12}$ Although serving as classic tyrosine kinase membrane receptors activating proliferation and survival, cell adhesion, and migration in malignant cells, all three subtypes are also expressed on macrophages, dendritic cells, and natural killer lymphocytes. ${ }^{13,14}$ Activation of TAM receptors limits the cytokine release after macrophage activation and mediates clearance of apoptotic cells by macrophages. ${ }^{15,16}$ Consequently, triple TAM knockout mice have the phenotype that resembles autoimmune disorder. ${ }^{17,18}$ A natural anticoagulant, protein $\mathrm{S}$, has been identified as a ligand for Tyro3 and Mer receptors. ${ }^{19,20}$ Originally described as a cofactor for activated protein $\mathrm{C}$-dependent inactivation of coagulation factors $\mathrm{Va}$ and VIIIa, ${ }^{21,22}$ protein $\mathrm{S}$ induces multiple coagulation-independent effects in a TAM receptor-dependent manner. Interestingly, in addition to regulation of macrophage and other immune cell function, protein $\mathrm{S}$ may activate TAM receptor subtypes expressed on nonimmune cell types, including endothelial and epithelial cells or neurons. For instance, protein $\mathrm{S}$ protects against various types of central nervous system or lung injury through activation of the Tyro3 receptor. ${ }^{23-25}$ Protein $\mathrm{S}$ has much lower affinity toward Axl, which preferentially binds to the growth arrest-specific protein (Gas-6), a noncoagulant soluble protein that shares a significant homology with protein S. ${ }^{19,20}$ Gas-6/Axl axis has been recently extensively studied in the kidney, and Gas- 6 activation of the mesangial Axl receptor has been implicated in the development of glomerular damage in several glomerulopathies, including DN. ${ }^{26,27}$ In contrast to Gas-6/Axl, little is known about the role of protein $\mathrm{S}$, Tyro3, and Mer in the development of renal disease.

Interestingly, extracellular domains of TAM receptors can be proteolytically cleaved by metalloproteases to yield soluble receptor forms designated sTyro3, sMer, and sAxl. ${ }^{28-30}$ All three soluble TAM (sTAM) receptors can be found in plasma, although their role has not been characterized yet. Such soluble forms might function as decoy receptors to inactivate their respective circulating ligands ${ }^{28}$ or even possess specific effects antagonistic to those of the canonical ligands. ${ }^{31}$ Excessive circulating levels of sMer, indicating increased systemic shedding, have been recently related to the severity of nephritis in patients with lupus $^{30}$ and to the severity of renal function decline in patients with chronic kidney disease of variable origin. ${ }^{32}$ However, systemic levels of sTAM receptors in patients with diabetes have not been studied so far. Although highmolecular-weight proteins, such as sTAM receptors (approximately $150 \mathrm{kDa}$ ), are unlikely to be filtered under normal conditions, we hypothesize that specific subtypes of TAM receptors might be expressed in the normal and in the diabetic kidney, and eventually, the soluble forms of the receptors might be released to urine. Furthermore, we propose that on metabolic and inflammatory injury in DN, renal expression and urinary and plasma levels of sTAM receptors might be altered.

\section{Materials and Methods}

\section{Patients}

The study was approved by the local ethical committee of the Slotervaart Hospital, Amsterdam, the Netherlands. A total of 126 patients from a larger, previously described ${ }^{33}$ cohort of patients with type 2 diabetes were included in the study. The cohort was recruited between May 2009 and December 2010 and consisted of patients visiting the Department of Internal Medicine, Slotervaart Hospital, for their annual comprehensive diabetes evaluation. Patients with urinary albumin excretion (UAE) levels $>300 \mathrm{mg} / 24$ hours (macroalbuminuria, indicating presence of a diabetic renal injury, $n=67$ ) and with available blood and 24-urine samples were identified and assigned to a DN study group. A similar number of patients with UAE levels $<30 \mathrm{mg} / 24$ hours (normoalbuminuria, patients with diabetes without $\mathrm{DN}$, diabetic control group, $n=59$ ) was randomly selected. A minimal sample size of 52 patients was calculated to detect a $25 \%$ difference in plasma level of sMer with a power of $80 \%$. In addition to UAE and glucose biochemistry, the patients were characterized in terms of plasma lipid profile and serum and urinary creatinine by standard biochemical assays, as described previously. ${ }^{33}$

Both blood and urine samples were centrifuged at $2000 \times g$ to obtain EDTA plasma and urine supernatant, respectively. To characterize normal values for sTAM receptors in body fluids, plasma and urine were collected from 18 healthy volunteers (nonobese, without diabetes mellitus, metabolic syndrome, hypercholesterolemia, hypertension, cardiovascular, or renal disease, age $>40$ years).

In addition, histopathologic examination was performed using normal control tissue $(n=6)$ or a separate set of archived kidney biopsy specimens (Department of Pathology, Academic Medical Center, Amsterdam, the Netherlands) from patients with DN $(n=9)$, which were not part of the cohort described above.

For all patients with diabetes, a follow-up serum creatinine and urinary albumin-creatinine ratio (UACR) sample was collected. We used a doubling in the serum creatinine on follow-up compared with baseline or a doubling of UACR on follow-up compared with baseline as a clinical outcome measure. One patient with diabetes was lost to follow-up.

\section{ELISAs for TAM Receptor Subtypes}

DuoSet enzyme-linked immunosorbent assay (ELISA) kits for human Tyro3 or Axl or Mer receptor (R\&D Systems, Minneapolis, MN) were used to determine plasma and urine levels of sTAM receptor subtypes, as well as sTAM receptor 
concentrations in cell culture supernatant (see below). After the coating of 96-well ELISA plates with the respective monoclonal capture antibodies, the plate was blocked with $3 \%$ fish gelatin (Sigma-Aldrich, St. Louis, MO) in trisbuffered saline and Tween 20 buffer $(20 \mathrm{mmol} / \mathrm{L}$ Tris, 150 $\mathrm{mmol} / \mathrm{L} \mathrm{NaCl}, \mathrm{pH} \mathrm{7.4,0.1 \%}$ Tween 20). Washing steps with phosphate-buffered saline and Tween $20(3.2 \mathrm{mmol} / \mathrm{L}$ $\mathrm{Na}_{2} \mathrm{HPO}_{4}, 0.5 \mathrm{mmol} / \mathrm{L} \mathrm{KH}_{2} \mathrm{PO}_{4}, 1.3 \mathrm{mmol} / \mathrm{L} \mathrm{KCl}, 135$ $\mathrm{mmol} / \mathrm{L} \mathrm{NaCl}, 0.1 \%$ Tween 20 ) were performed after the blockade and each subsequent incubation. EDTA plasma was diluted 1:10 in all cases, whereas 24-hour urine samples were diluted by factors 8,20 , and 4 for sTyro3, sAxl, and sMer, respectively. The diluted samples and serial dilutions of standards (recombinant Tyro3, recombinant Axl, and recombinant Mer, respectively) were added to the plate and subsequently incubated with the respective biotinylated polyclonal detection antibodies. After the addition of horseradish peroxidase-conjugated streptavidin, the color reaction was initiated using hydrogen peroxide and tetramethylbenzidine, and the absorbance was measured using automated plate reader. The concentrations were calculated using regression analysis to the respective standard curves. Renal clearance of specific sTAM receptors was calculated as [urinary concentration (nanograms per milliliter) $\times$ daily urine volume (milliliters)]/[plasma concentration (nanograms per milliliter) $\times 24$ hours $\times 60$ minutes].

\section{Western Blot Analysis}

Molecular weights of the urinary sTAM receptors were determined by Western blot analysis in urine samples of 12 randomly chosen study participants (four healthy, four with normoalbuminuria, and four with macroalbuminuria). Protein concentrations were determined by the bicinchoninic acid method, and equal amounts of protein were resuspended in Laemmli sample buffer and boiled for 10 minutes at $95^{\circ} \mathrm{C}$. The proteins were separated by SDS-PAGE on polyacrylamide gels (Thermo Fisher Scientific, Landsmeer, the Netherlands) and transferred to Immobilon-P nitrocellulose membranes by blotting for 2 hours (BioRad, Transblot SD, Hercules, CA). The membranes were blocked for 1 hour in tris-buffered saline and Tween $20(20 \mathrm{mmol} / \mathrm{L}$ Tris, $150 \mathrm{mmol} / \mathrm{L} \mathrm{NaCl}, 1 \%$ Tween, $\mathrm{pH} \mathrm{7.5)/5 \%} \mathrm{nonfat} \mathrm{dry} \mathrm{milk}$ and incubated overnight at $4{ }^{\circ} \mathrm{C}$ with the primary antibodies mouse anti-Tyro3 monoclonal and rabbit anti-Mer monoclonal (both LifeSpan Biosciences, Seattle, WA) and goat anti-Axl polyclonal (R\&D Systems). Membranes were washed and incubated with the corresponding secondary antibody, and immunoreactivity was visualized using ECL PLUS Western blotting detection reagent (GE Healthcare Europe, Diegen, Belgium).

\section{Total and Free Protein S ELISA}

Total protein S levels were determined as described previously $^{34}$ with an in-house ELISA (using antibodies from
Dako, Glostrup, Denmark). Free protein $\mathrm{S}$ was measured by precipitating the $\mathrm{C} 4 \mathrm{~b}$-binding protein-bound fraction with polyethylene glycol 8000 , followed by the measurement of the concentration of free protein $\mathrm{S}$ in the supernatant.

\section{Immunohistochemistry}

Paraffin-embedded sections of the kidney biopsy specimens from healthy individuals and patients with diabetes were stained for TAM receptor subtypes using mouse anti-Tyro3 monoclonal and rabbit anti-Mer monoclonal (both LifeSpan Biosciences), goat anti-Axl polyclonal (R\&D Systems), rabbit anti-protein S polyclonal (Sigma-Aldrich), and mouse anti-CD68 monoclonal (Dako) primary antibodies. After incubation with the respective peroxidase-conjugated secondary antibodies, the staining was developed with diaminobenzidine kit. The specificity of the anti-TAM antibodies was confirmed by a characteristic staining pattern in testicular epithelium. All sections were coded and scored by two blinded investigators (L.L. and J.J.T.H.R.) simultaneously by means of consensus. Intensity and abundance of glomerular, tubular, and interstitial signal were scored on a semiquantitative scale from 0 to 3 (absent, weak, moderate, or strong, respectively). For each section, a mean score was calculated from at least seven high-power fields.

For double staining of individual TAM receptors with the macrophage marker CD68, co-incubation of the individual primary antibodies was followed by the corresponding species-compatible secondary antibodies and visualized by Nova Red peroxidase and Vector Blue alkaline phosphatase kits, respectively (Vector Laboratories, Burlingame, CA).

\section{Cell Culture}

Human tubular epithelial HK-2 cells (ATCC, Manassas, VA) were grown to subconfluence in Dulbecco's modified Eagle's medium F12 medium (Invitrogen, Carlsbad, CA) (3:1) containing $10 \%$ fetal bovine serum, $2 \mathrm{mmol} / \mathrm{L} \mathrm{L}$-glutamine, $100 \mathrm{U} /$ $\mathrm{mL}$ penicillin, and $100 \mu \mathrm{g} / \mathrm{mL}$ streptomycin in a humidified $5 \% \mathrm{CO}_{2}$ atmosphere at $37^{\circ} \mathrm{C}$. Cells were serum starved for 24 hours and then stimulated with $30 \mathrm{mmol} / \mathrm{L}$ of glucose (or 30 $\mathrm{mmol} / \mathrm{L}$ of mannitol as osmotic control) and $10 \mathrm{ng} / \mathrm{mL}$ of transforming growth factor (TGF)- $\beta$ to model the diabetic environment for 48 hours as described previously, ${ }^{35}$ after which supernatant was collected and cells were harvested after washing with phosphate-buffered saline. Cell viability was assessed by the standard trypan blue exclusion test. ${ }^{36}$ Cellular TAM receptor mRNA expression was studied by real-time PCR. First, RNA was extracted from the cells using the Trizol reagent (Life Technologies), according to the protocol recommended by the manufacturer. RNA concentration and purity were determined by the Nanodrop spectrophotometer (Thermo Fisher Scientific), and cDNA was synthesized using oligo dT primers and reverse transcription mix (Roche Applied Science, Penzberg, Germany). Specific primers for the PCR were designed using the 
Primer-BLAST software version 2.6.0+ (https://www.ncbi. nlm.nih.gov/tools/primer-blast; National Center for Biotechnology Information Tools). The primers sequences were as follows: Tyro3 forward: 5'-GCGAGCAGCACTGGATCGGC-3' ${ }^{\prime}$, reverse: 5'-GTTCAGGGGGACCCACAGCCT-3'; Axl forward: 5'-GCAAGCACAGCCAGTCCACCAG- $3^{\prime}$, reverse: $5^{\prime}$-GCCAAGATGAGGACACAGGCAGC-3'; Mer forward: 5'-ACGTGTGGCAGAGTGCAGGGA-3', reverse: 5'-GCCCAACTCCCCCTCTGGTGA-3'; housekeeping gene TBP forward: 5'-CCCATGACTCCCATGACC-3', reverse: 5'-TTTACAACCAAGATTCACTGTGG-3'. For each PCR, a mastermix was prepared on ice, containing SensiFAST SYBR no-ROX mix (Bioline Reagents Ltd, London, UK), reverse and forward primers. The LightCycler 480 Real-Time PCR System (Roche Applied Science) was used with a 384-multiwell plate format. TAM receptor mRNA was normalized against $T B P$ mRNA expression. Results presented represent at least three independent experiments.

\section{Statistical Analysis}

Graphpad Prism version 7 (Graphpad Software, La Jolla, CA) was used for all statistical analyses. The R computation environment was used to plot the correlation matrices and to calculate the receiver operating characteristics curve analyses (c-indices). Comparisons between groups were performed using the Mann-Whitney test or Kruskal-Wallis test followed by Dunn post hoc comparisons, as appropriate.
$P<0.05$ was considered significant for all tests. Spearman rank correlation coefficients were calculated to study the association (correlations) between STAM receptors' levels and clinical variables and to calculate multicollinearity in the correlation matrix. Renal clearance of specific sTAM receptors was calculated as follows: [urinary concentration (nanograms per milliliter) $\times$ daily urine volume (milliliters)]/[plasma concentration (nanograms per milliliter) $\times 24$ hours $\times 60$ minutes].

The fractional excretion of the sTAM receptors (ie, the renal clearance of the sTAMs relative to the renal clearance of creatinine) was calculated as follows: $[100 \times$ (urinary sTAM concentration $\times$ plasma creatinine concentration)/ (plasma sTAM concentration $\times$ urinary creatinine concentration)].

To assess the performance of the measured parameters as markers to discriminate between patients with diabetes with and without albuminuria doubling of serum creatinine or a doubling of UACR on follow-up, receiver operating characteristics curve analysis was performed.

\section{Results}

\section{Cohort Characteristics}

The characteristics of both patient groups and healthy controls are given in Table 1. As expected, patients with macroalbuminuria in DN group had significantly higher serum creatinine levels and reduced estimated glomerular filtration

Table 1 General Characteristics of the Patients with Type 2 Diabetes Mellitus and Macroalbuminuria and Normoalbuminuria Compared with Healthy Controls

\begin{tabular}{|c|c|c|c|c|}
\hline \multirow[b]{2}{*}{ Parameter } & \multicolumn{2}{|c|}{ Type 2 diabetes mellitus } & \multirow[b]{2}{*}{$\begin{array}{l}\text { Healthy controls } \\
(n=18)\end{array}$} & \multirow[b]{2}{*}{$P$ value } \\
\hline & $\begin{array}{l}\mathrm{UAE}<30 \mathrm{mg} / 24 \\
\text { hours }(n=59)\end{array}$ & $\begin{array}{l}\text { UAE }>300 \mathrm{mg} / 24 \\
\text { hours }(n=67)\end{array}$ & & \\
\hline Males, $n(\%)$ & $21(36)$ & $54(81)$ & $8(44)$ & $<0.001$ \\
\hline Age, years & $62(32-81)$ & $64(38-89)$ & $52(41-64)$ & 0.04 \\
\hline Diabetes duration, years & $13(2-30)$ & $13(3-34)$ & NA & 0.40 \\
\hline Body mass index & $28(21-54)$ & $31(19-45)$ & $23(21-27)$ & 0.03 \\
\hline Smoking history, $n(\%)$ & $28(47)$ & $39(58)$ & NA & 0.30 \\
\hline Fasting glucose, $\mathrm{mmol} / \mathrm{L}$ & $7.6(4.8-18.3)$ & $9.6(4.8-18.0)$ & $4.8(3.8-6.6)$ & 0.03 \\
\hline $\mathrm{HbA}_{1 \mathrm{C}}, \%$ & $7.1(4.1-13.2)$ & $7.6(5.7-10.3)$ & $5.4(5.0-5.8)$ & 0.40 \\
\hline Insulin therapy, $n(\%)$ & $54(92)$ & $66(99)$ & NA & 0.10 \\
\hline Total cholesterol, mmol/L & $4.3(2.5-7.9)$ & $4.0(2.7-7.7)$ & $5.3(4.2-6.6)$ & 0.20 \\
\hline $\mathrm{HDL}-\mathrm{C}, \mathrm{mmol} / \mathrm{L}$ & $1.1(0.4-2.7)$ & $0.9(0.6-3.1)$ & $1.4(0.8-1.8)$ & 0.007 \\
\hline LDL-C, mmol/L & $2.4(0.9-4.5)$ & $2.0(0.6-5.6)$ & $3.1(2.3-3.8)$ & 0.10 \\
\hline $\mathrm{SBP}, \mathrm{mm} \mathrm{Hg}$ & $119(88-154)$ & $135(105-186)$ & $120(100-135)$ & $<0.001$ \\
\hline $\mathrm{DBP}, \mathrm{mm} \mathrm{Hg}$ & $72(55-86)$ & $78(58-99)$ & $78(60-85)$ & $<0.001$ \\
\hline $\mathrm{UAE}, \mathrm{mg} / 24$ hours & $0(0-12)$ & $755(305-8540)$ & $0(0-13)$ & $<0.001$ \\
\hline Serum creatinine, $\mu \mathrm{mol} / \mathrm{L}$ & $75(40-112)$ & $101(56-272)$ & $76(60-93)$ & $<0.001$ \\
\hline $\mathrm{eGFR}_{\mathrm{MDRD}}, \mathrm{mL} / \mathrm{min}$ & $86(55-162)$ & $65(20-111)$ & $100(78-134)$ & $<0.001$ \\
\hline ACEi/ARB therapy, $n(\%)$ & $1(2)$ & $60(90)$ & NA & $<0.001$ \\
\hline
\end{tabular}

Data are expressed as median (range) unless otherwise indicated.

*UAE $<30 \mathrm{mg} / 24$ hours versus UAE $>300 \mathrm{mg} / 24$ hours.

ACEi, angiotensin-converting enzyme inhibitor; ARB, angiotensin II receptor blocker; DBP, diastolic blood pressure; eGFR $\mathrm{MDRD}_{\text {, estimated glomerular }}$ filtration rate determined by the Modification of Diet in Renal Disease; HDL-C, high-density lipoprotein cholesterol; LDL-C, low-density lipoprotein cholesterol; NA, not applicable; SBP, systolic blood pressure; UAE, urinary albumin excretion. 

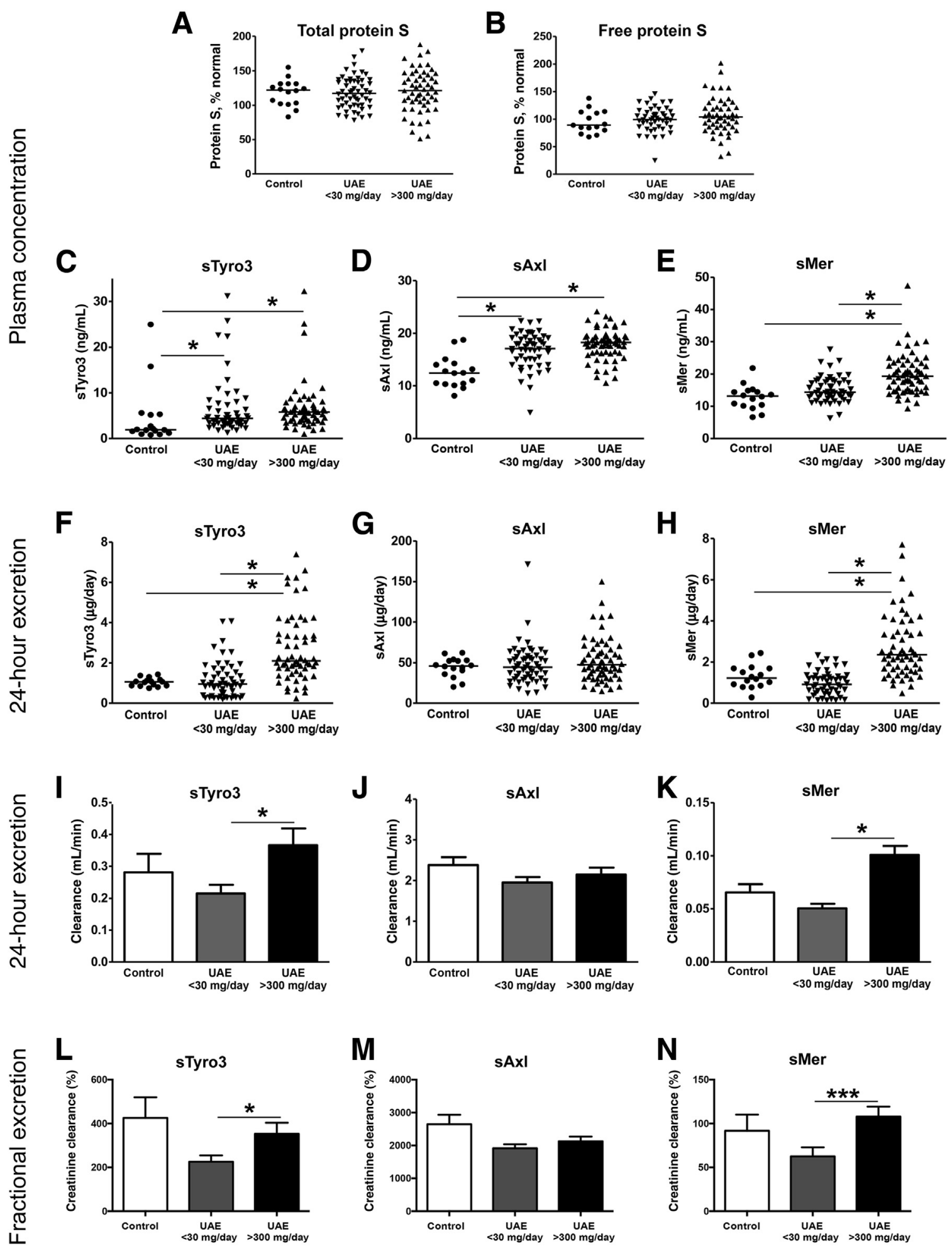

Figure 1 Comparison of plasma protein $\mathbf{S}$ levels $(\mathbf{A}$ and $\mathbf{B})$ and concentrations of soluble TAM receptors $(\mathbf{C}-\mathbf{E})$ in healthy controls and patients with type 2 diabetes with [urinary albumin excretion (UAE) $>300 \mathrm{mg} /$ day] and without (UAE $<30 \mathrm{mg} /$ day) diabetic nephropathy (DN). Urinary excretion (F-H), renal clearance $(\mathbf{I}-\mathbf{K})$, and fractional excretion $(\mathbf{L}-\mathbf{N})$ of soluble TAM receptors in healthy controls and patients with type 2 diabetes with (UAE $>300 \mathrm{mg} /$ day) and without (UAE $<30 \mathrm{mg} /$ day) DN. Data are expressed as means \pm SEM $(\mathbf{I}-\mathbf{N}) .{ }^{*} P<0.05,{ }^{* *} P<0.005$.

rate (eGFR), suggesting a significant decline in renal function when compared with controls with diabetes and normoalbuminuria. At the same time, the severity of diabetes was comparable in both study groups, as indicated by the lack of significant differences in $\mathrm{HbA}_{1 \mathrm{c}}$, duration of diabetes, and proportion of patients receiving insulin treatment. Still, patients with macroalbuminuria had increased body mass index (BMI), reduced high-density lipoprotein 
Table 2 Associations between the Levels of sTAM Receptors and Clinical Parameters Per Group

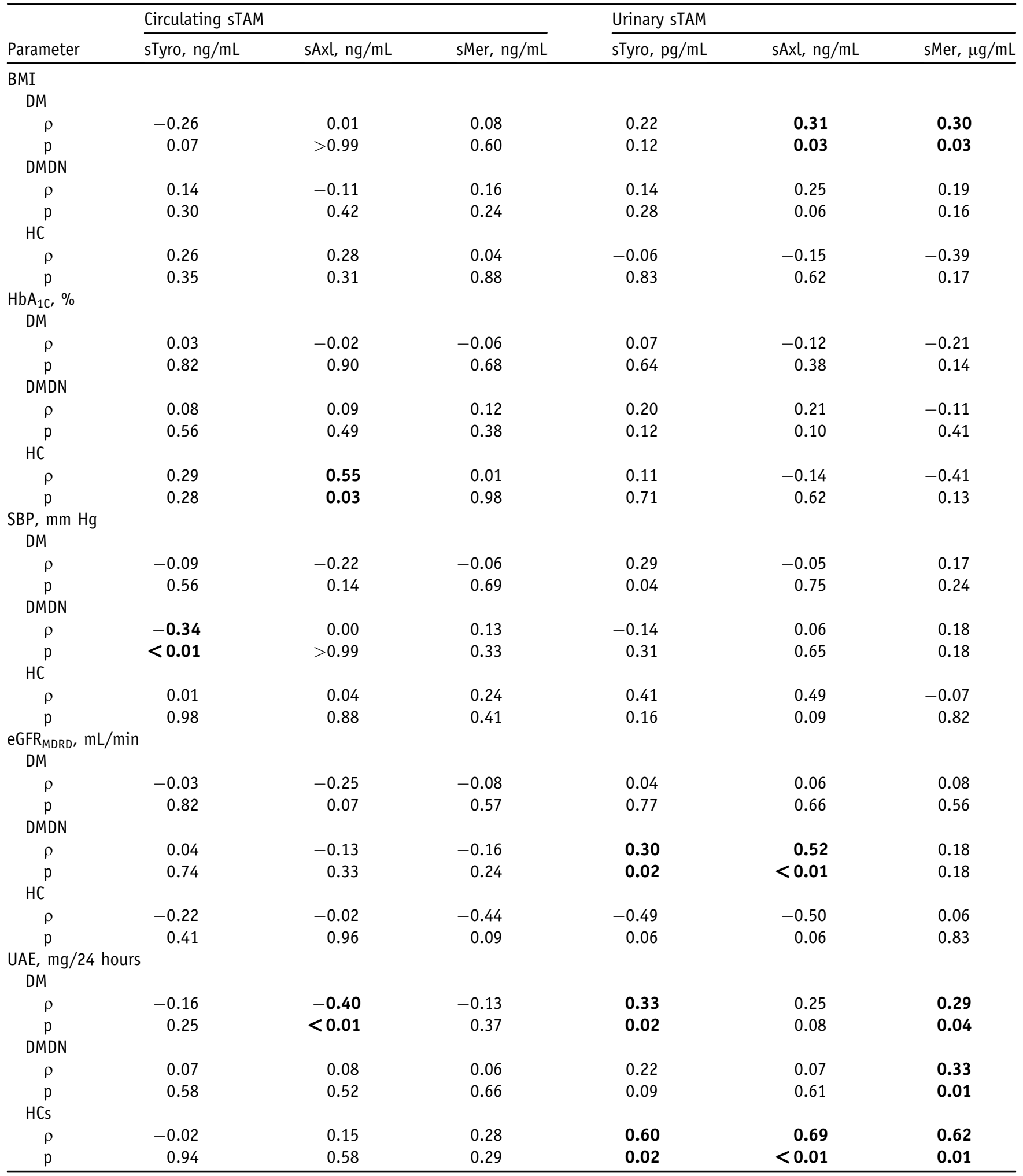

Numbers in bold indicate statistically significant associations.

BMI, body mass index; DBP, diastolic blood pressure; DM, diabetes mellitus without nephropathy; DMDN, diabetes mellitus with diabetic nephropathy; eGFR, estimated glomerular filtration rate determined by the Modification of Diet in Renal Disease; HCs, healthy controls; SBP, systolic blood pressure; sTAM, soluble TAM; UAE, urinary albumin excretion. 
Table 3 Absolute and Creatinine-Corrected Urinary Levels of sTAM Receptors in Healthy Controls and Patients with Diabetes with and without DN

\begin{tabular}{|c|c|c|c|}
\hline \multirow[b]{2}{*}{ sTAM receptor } & \multicolumn{3}{|c|}{ Urinary concentration } \\
\hline & Healthy controls & $\begin{array}{l}\text { Patients without DN } \\
\text { (UAE }<30 \mathrm{mg} / 24 \text { hours) }\end{array}$ & $\begin{array}{l}\text { Patients with } D N \\
\text { (UAE }>300 \mathrm{mg} / 24 \text { hours) }\end{array}$ \\
\hline sTyro, ng/mmolCr & $96(67-149)$ & $87(16-329)$ & $150{ }^{* \dagger}(12-632)$ \\
\hline $\mathrm{sAxl}, \mathrm{ng} / \mathrm{mL}$ & $22(9-39)$ & $24(5-56)$ & $23(6-54)$ \\
\hline $\mathrm{sAxl}, \mu \mathrm{g} / \mathrm{mmolCr}$ & $4(2-6)$ & $4(1-9)$ & $3(1-8)$ \\
\hline
\end{tabular}

cholesterol levels, and elevated blood pressure when compared with controls with diabetes. Finally, patients with DN were slightly older, and the proportion of males in this group was also higher than in controls with diabetes.

In line with the inclusion criteria, the healthy volunteers in the control group used to define normal values of sTAM receptors had normal glucose, $\mathrm{HbA}_{1 \mathrm{c}}$, blood pressure, cholesterol, and serum creatinine values.

\section{Plasma Levels of Total and Free Protein S in DN}

No significant differences were found between the study groups in plasma levels of total (Figure 1A), free (Figure 1B), or $\mathrm{C} 4 \mathrm{~b}$ binding protein-bound (data not shown) protein $S$, all approaching the levels measured in healthy individuals. Nevertheless, protein $\mathrm{S}$ levels correlated positively with the level of albuminuria $\left(r_{\mathrm{s}}=0.19\right.$, $P<0.05$ and $r_{\mathrm{s}}=0.24, P<0.01$ for total and free protein $\mathrm{S}$, respectively) and negatively to eGFR $\left(r_{\mathrm{s}}=-0.22\right.$, $P<0.01$ and $\left.r_{s}=-0.18, P<0.05\right)$ in the overall cohort.

\section{Plasma Levels of sTAM Receptor Subtypes in DN}

Soluble forms of all three subtypes of TAM receptors were detected in plasma of both healthy controls and patients with diabetes, indicating a nonnormal skewed distribution (Figure 1, C-E). No significant difference was found between the study groups with diabetes in sTyro3 levels [mean (range), 4.40 (1.29 to 31.20$) \mathrm{ng} / \mathrm{mL}$ versus 5.81 (0.97 to 32.2) $\mathrm{ng} / \mathrm{mL}$ ] (Figure 1C) or sAxl levels [mean (range), 17.1 (4.93 to 22.3 ) $\mathrm{ng} / \mathrm{mL}$ versus 18.3 (10.6 to 24.1 ) $\mathrm{ng} / \mathrm{mL}$, for patients without and with DN, respectively] (Figure 1D), although in both cases the levels were significantly higher than the values measured in healthy controls [mean (range), $1.93(0.79$ to 25.0$) \mathrm{ng} / \mathrm{mL}$ and 12.4 (8.10 to 18.7$) \mathrm{ng} / \mathrm{mL}$ for sTyro3 and sAxl, respectively].

On the other hand, sMer plasma levels were elevated [mean (range), 14.4 (6.31 to 27.6$) \mathrm{ng} / \mathrm{mL}$ versus 19.3 (9.29 to 47.4 ) $\mathrm{ng} / \mathrm{mL}, P<0.005$ ] (Figure $1 \mathrm{E}$ ) in patients with $\mathrm{DN}$ when compared with controls with diabetes, whereas no significant difference was found between the levels in patients without macroalbuminuria and healthy controls [mean (range), 13.2 (6.59 to 21.8$) \mathrm{ng} / \mathrm{mL}$ ].

Moreover, sMer systemic levels were significantly correlated with sTyro3 and sAxl levels in the whole cohort (sMer versus Tyro3 $r_{\mathrm{s}}=0.45, P<0.001$; sMer versus sAxl $\left.r_{\mathrm{s}}=0.37, P<0.001\right)$. Furthermore, plasma levels of sTyro3 were significantly related to the levels of $\mathrm{HbA}_{1 \mathrm{c}}$ and UAE; plasma levels of sAxl were significantly related to BMI, $\mathrm{HbA}_{1 \mathrm{c}}$, UAE, and eGFR; and sMer was positively correlated with BMI, $\mathrm{HbA}_{1 \mathrm{c}}$, systolic blood pressure, eGFR, and UAE in the complete study population (Table 2).

\section{Urinary Excretion of sTAM Receptor Subtypes in DN}

Intriguingly, all three sTAM receptor subtypes were excreted in the urine. Western blot analysis revealed that all three sTAM receptors were present in plasma and urine in full-length form (Axl, $120 \mathrm{kDa}$; Tyro3, $105 \mathrm{kDa}$; Mer, 200 $\mathrm{kDa}$ ) (Supplemental Figure S1). Absolute and creatinine corrected urinary levels are given in Table 3. Urinary concentrations of sTyro3 had skewed distribution and large variability (Table 3). Importantly, sTyro3 daily urinary excretion was increased more than twofold in patients with DN compared with patients with normoalbuminuric diabetes [mean (range), 0.94 (0.20 to 4.07$) \mu \mathrm{g} / 24$ hours versus 2.10 (0.24 to 7.40$) \mu \mathrm{g} / 24$ hours, $P<0.001$, for patients without and with DN, respectively] (Figure 1F). Control sTyro3 excretion did not differ from the excretion in normoalbuminuric patients [mean (range), 1.06 (0.74 to 1.43) $\mu \mathrm{g} / 24$ hours] (Figure 1F). To estimate the role of systemic versus renal contribution to urinary excretion of sTAM receptors, renal clearance was calculated for each individual TAM receptors subtype, as described in Materials and Methods. sTyro3 renal clearance was significantly higher in patients with DN when compared with controls with diabetes [mean (range), 0.17 (0.01 to 0.66$) \mathrm{mL} /$ minutes versus 0.25 (0.05 to 2.10) $\mathrm{mL} /$ minutes, $P<0.001$ ] (Figure 1I), suggesting 
Table 4 AUROC Analysis for the Prediction of Doubling of Urinary Albumin/Creatinine Ratio or Serum Creatinine on Follow-Up

\begin{tabular}{ll}
\hline Parameter & AUROC \\
\hline eGFR & $0.621(0.526-0.716)$ \\
Serum sTyro3 & $0.482(0.367-0.597)$ \\
Urine sTyro3 & $0.567(0.462-0.672)$ \\
FE sTyro3 & $0.515(0.396-0.634)$ \\
Serum sAxl & $0.552(0.445-0.659)$ \\
Urine sAxl & $0.517(0.409-0.626)$ \\
FE sAxl & $0.463(0.349-0.578)$ \\
Serum sMer & $0.468(0.358-0.578)$ \\
Urine sMer & $0.527(0.416-0.639)$ \\
FE sMER & $0.505(0.385-0.625)$ \\
\hline
\end{tabular}

Data are expressed as median (range).

AUROC, area under the receiver operating characteristic curve; eGFR, estimated glomerular filtration rate determined by the Modification of Diet in Renal Disease; FE, fractional excretion index; s, soluble; UACR, urinary albumin-creatinine ratio.

changes in renal sTyro3 handling (filtration/reabsorption) or active production of sTyro3 in the kidney on DN.

Although no changes were observed in urinary excretion of sAxl [mean (range), 46.0 (20.0 to 62.0) $\mu \mathrm{g} / 24$ hours versus 44.5 (12.2 to 171$) \mu \mathrm{g} / 24$ hours versus 47.5 (14.8 to 150) $\mu \mathrm{g} / 24$ hours] (Table 3 and Figure $1 \mathrm{G}$ ) or renal clearance [mean (range), 2.26 (1.25 to 3.20$) \mathrm{mL} /$ minute versus 1.82 (0.54 to 5.79$) \mathrm{mL} /$ minute versus 1.81 ( 0.54 to 6.52 ) $\mathrm{mL} /$ minute for healthy controls, patients with diabetes without $\mathrm{DN}$, and patients with diabetes and $\mathrm{DN}$, respectively] (Figure 1J), daily excretion of sMer was approximately doubled in patients with DN when compared with controls with diabetes or healthy controls [mean (range), 1.23 (0.28 to 2.440$) \mu \mathrm{g} / 24$ hours versus 0.91 ( 0.14 to 2.33 ) $\mu \mathrm{g} / 24$ hours versus 2.35 (0.49 to 7.72$) \mu \mathrm{g} / 24$ hours, $P<0.001$ ] (Table 3 and Figure $1 \mathrm{H}$ ). Furthermore, renal clearance of sMer was markedly increased as well [mean (range), $0.046(0.004$ to 0.137$) \mathrm{mL} /$ minute versus 0.087 (0.008 to 0.323 ) $\mathrm{mL} /$ minute, $P<0.001$ ] (Figure $1 \mathrm{~K}$ ), indicating that in addition to elevated systemic sMer, increased urinary sMer excretion is due to altered renal handling and/or production of sMer in the diabetic kidneys. In logistic regression, we observed that independent of the eGFR, sTyro3 and sMer but not sAxl (Supplemental Table S1) was associated with the prevalence of DN. A similar pattern was observed when the fractional excretion of the sTAM receptors (Figure 1, L-N) was investigated. In the theoretical situation of free STAM receptor filtration and no renal sTAM receptor excretion, the maximum fractional excretion is $100 \%$ (taking into account that no creatinine is excreted by the renal tubules). In healthy controls, but also in patients with diabetes (with or without macroalbuminuria), the fractional excretion exceeded $100 \%$ by a factor two to four for sTyro3 and a factor 18 to 26 for sAxl, indicating that potentially renal excretion (at least of these two sTAM receptors) takes place.

In the complete cohort, urinary levels of sTyro3 and sMer correlated positively with BMI, blood pressure, and UAE, whereas urinary sAxl was only related to BMI and eGFR levels (Table 3). There was a significant positive relation between systemic and urinary levels for sMer $(r=0.26$, $P<0.01)$ but not sTyro3 or sAxl. In the correlation matrix, we observed that particularly in healthy individuals, the fractional excretion indices of the sTAM receptors were strongly correlated with the corresponding serum concentrations (Supplemental Figure S2A). This pattern was lost in patients with diabetes with or without nephropathy (Supplemental Figure S2, B and C).

\section{Follow-Up and Predictive Value of sTAM Receptors}

On follow-up, $39 \%$ of the patients with diabetes mellitus had a doubling in UACR or a doubling of their serum creatinine level compared with baseline. The sTAM receptors in the serum, the urine, or their fractional excretion were not better at predicting progressive DN than albuminuria or the Modification of Diet in Renal Disease eGFR (Table 4).

\section{Protein S Immunoreactivity in the Diabetic Kidneys}

Being a typical systemic liver-derived circulating anticoagulant protein, protein $\mathrm{S}$ immunoreactivity would not be readily expected in organs, such as kidneys, under normal conditions. Indeed, control renal biopsy specimens were largely protein $\mathrm{S}$ negative, with only minor positivity in tubuli (Figure 2A), possibly reflecting reabsorption of the filtered protein. In contrast, DN is characterized by prominent glomerular deposition of protein S (Figure 2, B and C), whereas no significant difference was noted in tubular protein S signal (Figure 2D).

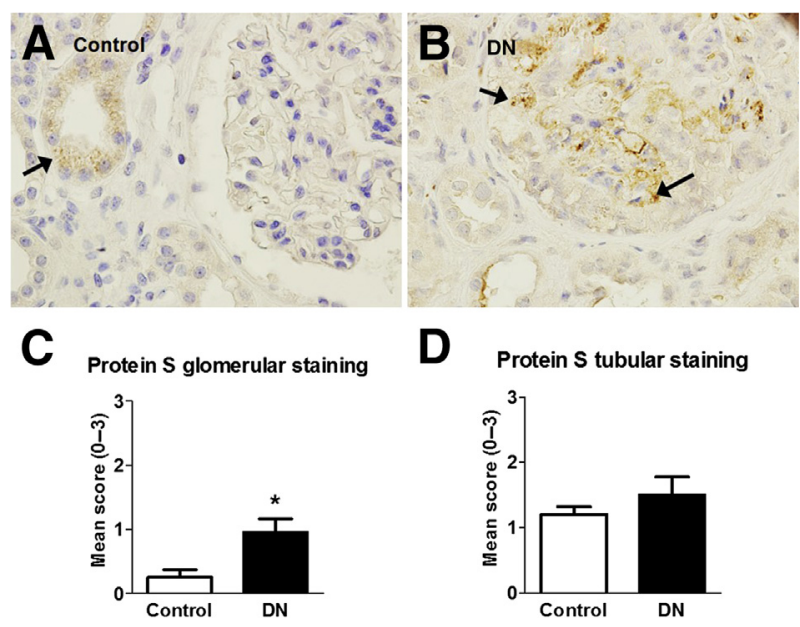

Figure 2 Representative immunohistochemical staining of protein $\mathrm{S}$ in the control kidneys (A; arrow indicate a positive staining of tubular epithelial cells) and in the kidneys of patients with diabetic nephropathy (DN) (B; arrows indicate extensive glomerular depositions of protein S). Quantitative comparison of glomerular (C) and tubular (D) score of protein $S$ staining in control and diabetic kidneys. Data are expressed as means \pm SEM. ${ }^{*} P<0.05$ versus control. Original magnification, $\times 20$. 

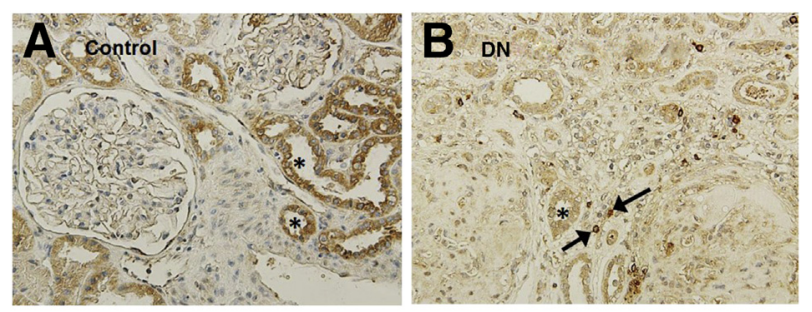

C Tyro3 glomerular staining
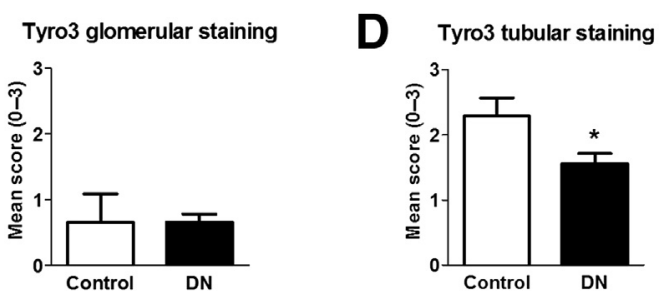

E
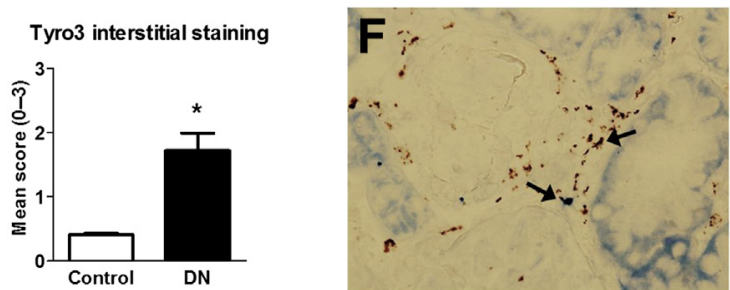

Figure 3 A and B: Immunohistochemical staining of Tyro3 receptor in the control kidneys $(\mathbf{A})$ and in the kidneys of patients with diabetic nephropathy (DN) (B). Arrows indicate the positive interstitial cells; asterisks, the positive tubular epithelium. C-E: Quantitative comparison of glomerular (C), tubular (D), and interstitial (E) score of Tyro3 receptor staining in control and diabetic kidneys. F: Double staining of macrophage marker CD68 (red/brown) and Tyro3 (blue) shows co-localization (arrows) in the renal interstitium of patients with DN. Data are expressed as means \pm SEM. ${ }^{*} P<0.05$ versus control. Original magnification: $\times 10(\mathbf{A}$ and $\mathbf{B}) ; \times 20(\mathbf{F})$.

\section{Changes in Renal Expression of TAM Receptor Subtypes in the Kidney after DN}

All three subtypes of TAM receptors were found to be expressed in control and diabetic human kidneys by immunohistochemistry. Tyro3 was abundantly expressed in proximal tubular epithelium (Figure 3A), and mild positivity was observed in glomeruli (podocytes and endothelial cells). The latter was not altered in diabetic kidneys (Figure 3C); however, epithelial Tyro3 expression was markedly reduced in DN (Figure 3, B and D). Interestingly, abundant interstitial influx of Tyro3-positive infiltrating cells (Figure 3B), presumably macrophages, was found in diabetic kidneys, although such cells were also observed in normal kidneys, albeit in markedly lower number (Figure 3E). Using macrophage marker CD68 and Tyro3 staining, massive interstitial influx of macrophages in diabetic kidneys with numerous cells double positive for both the macrophage marker and Tyro3 receptor was confirmed (Figure 3F).

In contrast to ubiquitous renal expression of Tyro3, Mer receptor had a more restricted expression pattern, including specific subset of tubular epithelial cells, presumably in proximal portions, often strongly localized in the cell membrane (Figure 4A). Little glomerular and weak interstitial expression of Mer was noticed in control kidneys. No changes in glomerular Mer expression were found in diabetic kidneys (Figure 4C). On the other hand, in diabetic kidneys, loss of tubular Mer staining (Figure 4, B and D) was associated with increased presence of Mer-positive interstitial cells (Figure 4, B and E). Comparable to Tyro3 interstitial expression pattern, macrophage marker CD58 co-localized with Mer receptor in the renal interstitium (Figure 4F).

Finally, Axl receptor was prominently expressed in glomeruli and renal vasculature, reflecting endothelial localization of this subtype (Figure 5A). In addition, clear membrane staining of Axl was noticed in proximal tubuli (Figure 5A). Although hardly any changes were observed in Axl glomerular (Figure 5, B and C) or tubular (Figure 5, B and D) staining after DN, some CD68-positive interstitial macrophages had expression as well (Figure 5, E and F).

\section{Differential Expression of TAM Receptor Subtypes by Tubular Epithelial Cells in Vitro}

To further gain insight in the regulation of TAM receptor expression by tubular epithelial cells, human kidney HK-2
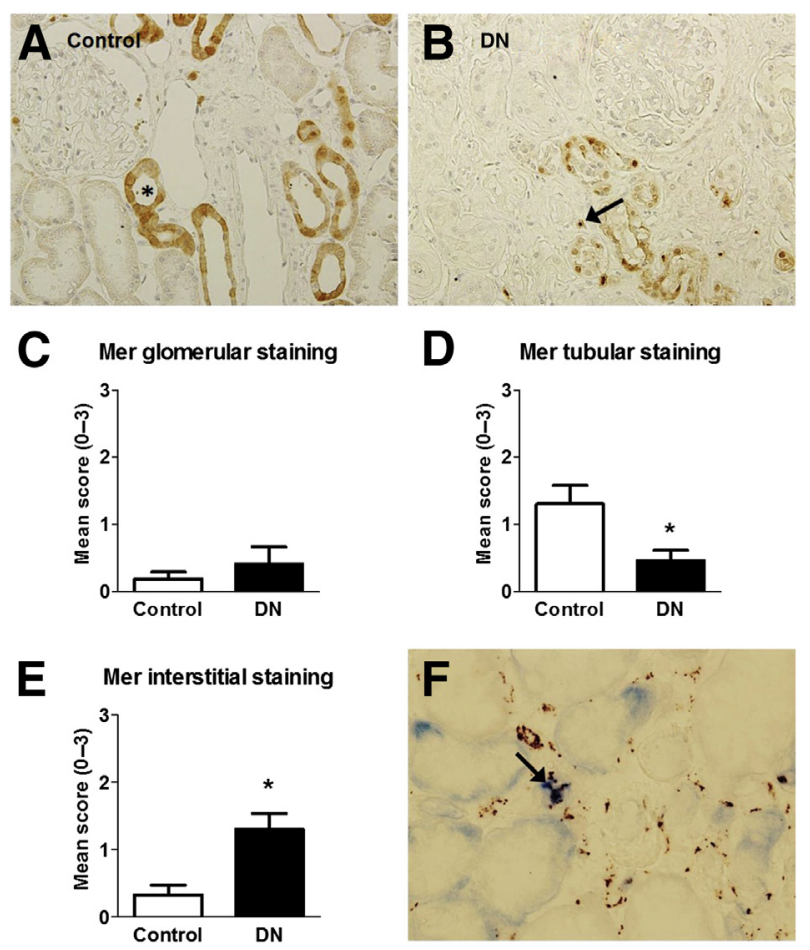

Figure 4 A and B: Immunohistochemical staining of Mer receptor in the control kidneys (A; asterisk indicates the positive tubular epithelium) and in the kidneys of patients with diabetic retinopathy (DN) (B; arrow indicates a positive interstitial cell). C-E: Quantitative comparison of glomerular (C), tubular (D), and interstitial (E) score of Mer receptor staining in control and diabetic kidneys. F: Double staining of macrophage marker CD68 (red/brown) and Mer (blue) shows co-localization (arrow) in the renal interstitium of patients with DN. Data are expressed as means \pm SEM. ${ }^{*} P<0.05$ versus control. Original magnification: $\times 10$ $(\mathbf{A}$ and $\mathbf{B}) ; \times 20(\mathbf{F})$. 


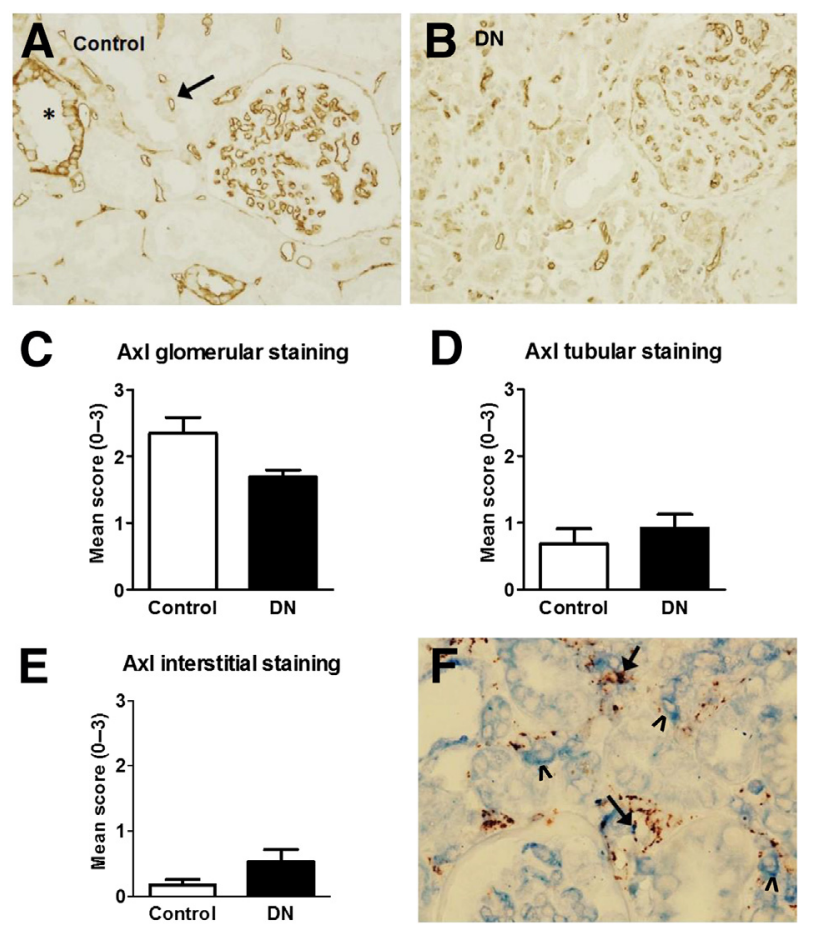

Figure $5 \quad$ A and B: Immunohistochemical staining of Axl receptor in the control kidneys $(\mathbf{A})$ and in the kidneys of patients with diabetic retinopathy (DN; B). Asterisk indicates the positive tubular epithelium; arrow, interstitial vascular staining. C-E: Quantitative comparison of glomerular (C), tubular (D), and interstitial (E) score of Axl receptor staining in control and diabetic kidneys. F: Double staining of macrophage marker CD68 (red/ brown) and Axl (blue) shows co-localization (arrows) in the renal interstitium of patients with DN. Arrowheads point to the vascular Axl staining of vascular endothelium. Data are expressed as means \pm SEM. Original magnification: $\times 10(\mathbf{A}$ and $\mathbf{B}) ; \times 20(\mathbf{F})$.

cells were cultured under diabetic conditions, using an established in vitro model of diabetic milieu. ${ }^{35}$ Incubation of cells with high glucose and transforming growth factor- $\beta$ levels for 48 hours resulted in significant down-regulation of Tyro 3 and Mer mRNA, although Tyro3 mRNA levels were not different between the high-glucose and osmotic control circumstances (Figure 6, A and C). Axl mRNA levels remained unchanged among the different experimental conditions (Figure 6B). Interestingly, sTAM receptor protein concentrations in the culture supernatants did not reflect the cellular mRNA levels. sTyro3 and Mer levels were significantly increased after 48 hours of incubation with high glucose and transforming growth factor- $\beta$ levels (Figure 6, D and F). Again, no differences were measured with respect to the sAxl levels in the culture supernatants (Figure 6E). Taken together, these data suggest that diabetic circumstances result in down-regulation of Tyro3 and Mer on the mRNA level but at the same time cause increased shedding of the Tyro3 and Mer receptor proteins.

\section{Discussion}

In the present study, we provide evidence that type 2 diabetes is associated with excessive circulating levels of
sTAM receptors sTyro3 and sAxl, whereas sMer levels are increased only in patients with diabetes and DN. Surprisingly, all sTAM receptors are excreted in the urine, and urinary excretion of sTyro3 is enhanced in patients with diabetes and DN. This is associated with the loss of tubular Tyro3 and Mer expression in diabetic kidneys. In vitro, tubular epithelial cells respond to diabetic circumstances with a down-regulation of Tyro3 and Mer mRNA production, and at the same time the shedding of sTyro3 and sMer is increased. Furthermore, DN is characterized by excessive infiltration of Mer-, Tyro3-, and Axl-positive macrophages and glomerular deposition of TAM ligand protein S.

So far, elevations in circulating levels of TAM receptors sMer and sTyro3 have been reported in patients with autoimmune disease, including systemic lupus erythematosus and rheumatoid arthritis. ${ }^{30,37,38}$ It has been proposed that excessive sMer levels might reflect impaired clearance of apoptotic debris and excessive cytokine production by macrophages and dendritic cells, both key pathologic characteristics of autoimmune disease. The current study suggests that a primarily nonimmune disease, such as type 2 diabetes, might be associated with systemic elevations of sTAM receptors as well. Diabetes mellitus is characterized by chronic low-grade inflammation, activation of innate immune system, and elevated systemic levels of cytokines, such as IL-1 $\beta$, IL- 6 , or tumor necrosis factor- $\alpha,{ }^{39}$ potentially negatively regulated by TAM receptors. Direct correlations between circulating levels of sTyro3, sAxl, and sMer on the one hand and clinical parameters, such as BMI or the level of glycemic control $\left(\mathrm{HbA}_{1 \mathrm{c}}\right)$, on the other hand may suggest that elevations of TAM receptors in patients with diabetes are the reflection of such systemic metabolically induced inflammation. Possibly, systemic or resident immune cells, such as monocytes or macrophages, might represent the primary source for circulating TAM receptor elevations, although TAM receptors are expressed by many other systemic cell types, including vascular endothelium and platelets. ${ }^{40,41}$ For instance, shedding of the sMer domain in macrophages is probably initiated by metalloproteinase ADAM17. ${ }^{29}$ Increased ADAM17 expression along with reduced Mer expression have been recently described in circulating monocytes isolated from patients undergoing dialysis. ${ }^{32}$ On the other hand, in our study, systemic levels of sMer were increased only in patients with DN when compared with patients with diabetes and normoalbuminuria. This finding is in line with a previous finding that renal function loss is associated with increase in sMer circulating levels in a mixed population of patients with chronic kidney disease. ${ }^{32}$ Increase of systemic sMer levels on renal injury might reflect more severe cardiovascular and metabolic dysfunction associated with impaired renal function or alternatively indicate contribution of kidneyderived sMer to circulating levels. Indeed, in the current study, DN was characterized by excessive renal TAM receptor-positive macrophage infiltration and reductions in Tyro3 and Mer receptor expression in renal cell types, such 

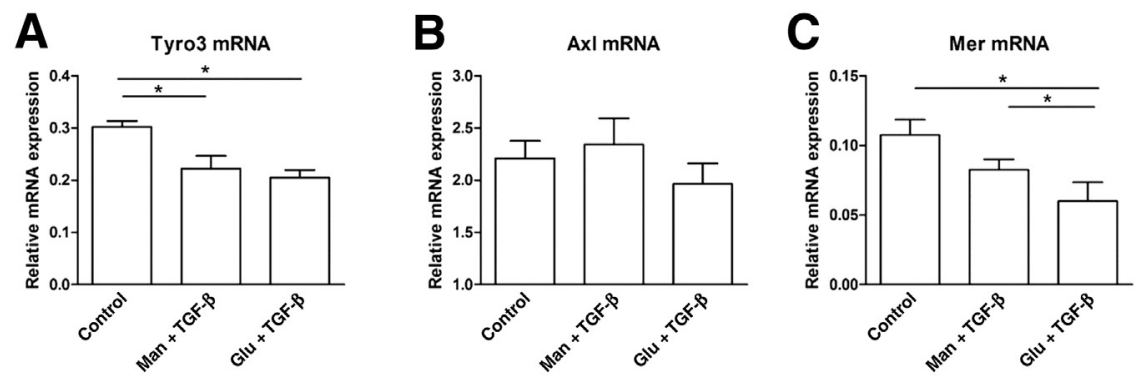

Figure 6 TAM receptor production and shedding in human tubular epithelial cells. A and C: Incubation of cells with high glucose $(30 \mathrm{mmol} / \mathrm{L})$ and $10 \mathrm{ng} / \mathrm{mL}$ of transforming growth factor (TGF)$\beta$ for 48 hours results in significant downregulation of Tyro 3 (A) and Mer mRNA (C), although Tyro33 mRNA levels are not different between the high-glucose and osmotic (mannitol) control circumstances. B: Axl mRNA levels remain unchanged among the different experimental conditions. Soluble TAM (sTAM) receptor protein concentrations in the supernatant were determined by enzyme-linked immunosorbent assay. D and F: Soluble Tyro3 (sTyro3) (D) and soluble Mer (sMer) (F) levels are significantly increased after 48 hours incubation with high glucose $(30 \mathrm{mmol} /$ $L)$ and $10 \mathrm{ng} / \mathrm{mL}$ of TGF- $\beta$. E: sAxl levels remain unchanged. Data are expressed as means \pm SEM. $n=3$ independent experiments. ${ }^{*} P<0.05$, ${ }^{* *} P<0.01$. AU, arbitrary units; Glu, glucose; Man, mannitol.

as tubular epithelium. Notably, we recently found an excessive renal expression of Mer-shedding protease ADAM17 in patients with DN. ${ }^{35}$ Collectively, in contrast to sTyro3 and sAxl levels affected only by metabolic and/or cardiovascular disease, systemic sMer concentration is directly or indirectly elevated by diabetic renal dysfunction. It remains unclear whether renal shedding of Mer receptor might contribute to the systemic changes.

Intriguingly, we have found all three soluble receptors being excreted in urine in a range of micrograms per day. This is the first study to find urinary excretion of sTAM receptors in healthy individuals and patients with diabetes. It is a rather surprising finding because the soluble forms of TAM receptors are high-molecular-weight proteins (105 to $200 \mathrm{kDa}^{31}$ that are not likely to be filtered in intact glomeruli. All three subtypes are expressed in tubular epithelium of normal as well as diabetic kidneys and could be shed in tubular lumen, leading to urinary excretion of sTAM. In addition, urinary excretion of sMer and sTyro3 is increased on diabetic renal injury when compared with patients with dibetes and normoalbuminuria. Interestingly, the fractional excretion of two of the sTAMs exceeds $100 \%$, which means that there is significant intrarenal production and shedding of TAMs into the urine. The observed reduced tubular expression of sTyro3 and sMer in diabetic kidney biopsy specimens supports this finding. Western blot analysis revealed that sTAM receptors are excreted in full-length form, which suggests active production of TAM receptors in the kidney under healthy and disease conditions. In addition, our in vitro data indicate decreased Tyro3 and Mer mRNA and increased Tyro3 and Mer shedding under diabetic circumstances. On the other hand, urinary sMer levels correlate with sMer circulating levels and in addition are directly proportional to the severity of albuminuria in patients with DN, indicating at least a partial contribution of excessive filtration through damaged glomeruli to urinary sMer excretion.

Because the exact role of TAM receptors in the development of kidney injury has not been defined so far, we can only speculate about the functional consequences of excessive sTAM shedding. TAM receptors are required for limitation of cytokine production in macrophages ${ }^{16,42}$; therefore, reduced expression and/or excessive shedding might contribute to the activation of circulating or renal interstitial macrophages on inflammatory injury. Furthermore, protein $\mathrm{S}$-induced activation of Tyro3 receptors protects microvascular endothelial cells against apoptosis and preserves endothelial barrier function. ${ }^{25,40}$ Because Tyro3 is expressed in glomeruli, it might contribute to the regulation of glomerular permeability. Interestingly, although circulating levels of protein $S$ were not different in patients with diabetes, we observed marked glomerular deposits of protein $\mathrm{S}$ in diabetic kidneys, suggesting that the TAM ligand local renal levels are increased on injury. Furthermore, systemic protein S levels were positively correlated with albuminuria in patients with diabetes. This is in line with a recent study that found elevated protein $\mathrm{S}$ levels in patients with chronic kidney disease ${ }^{43}$ The is similarly true for circulating levels of Gas- $6,{ }^{43}$ an additional ligand of Axl and other TAM subtypes. Glomerular Gas-6 has been proposed to stimulate mesangial Axl, inducing glomerular hypertrophy in $\mathrm{DN}^{26,44} \mathrm{We}$, however, did not detect any changes in Axl glomerular staining in our study. Furthermore, Gas-6 circulating levels could be related to systemic vascular pathology because Gas-6 and Axl expressed on vascular smooth muscle cells seem to be involved in prevention of vascular calcifications associated with chronic kidney disease. ${ }^{43,45}$ This was, however, not reflected by any changes in circulating sAxl levels in DN in the current study.

In conclusion, renal injury in type 2 diabetes is associated with elevated systemic levels of sMer and increased urinary 
excretion of sMer and sTyro3. In the current study, we found a measurable excretion of sTAM in the urine, attributable to filtration and local tubular production or shedding, thus identifying the kidney as a potential source of sTAM shedding. We could not establish an additional role for sTAM receptors as predictive biomarkers of renal functional decline besides albuminuria. Further studies will be required to gain better understanding of the mechanisms of TAM shedding in renal epithelial cells and the role of TAM receptors and their ligands in the development of renal injury.

\section{Supplemental Data}

Supplemental material for this article can be found at http://dx.doi.org/10.1016/j.ajpath.2017.05.004.

\section{References}

1. Collins AJ, Foley RN, Chavers B, Gilbertson D, Herzog C, Ishani A, et al: US Renal Data System 2013 Annual Data Report. Am J Kidney Dis 2014, 63(Suppl 1):A7

2. Gross JL, de Azevedo MJ, Silveiro SP, Canani LH, Caramori ML, Zelmanovitz T: Diabetic nephropathy: diagnosis, prevention, and treatment. Diabetes Care 2005, 28:164-176

3. Diez-Sampedro A, Lenz O, Fornoni A: Podocytopathy in diabetes: a metabolic and endocrine disorder. Am J Kidney Dis 2011, 58:637-646

4. Jefferson JA, Shankland SJ, Pichler RH: Proteinuria in diabetic kidney disease: a mechanistic viewpoint. Kidney Int 2008, 74:22-36

5. Satchell SC, Tooke JE: What is the mechanism of microalbuminuria in diabetes: a role for the glomerular endothelium? Diabetologia 2008, 51:714-725

6. Forbes JM, Cooper ME: Mechanisms of diabetic complications. Physiol Rev 2013, 93:137-188

7. Qian Y, Feldman E, Pennathur S, Kretzler M, Brosius FC III: From fibrosis to sclerosis: mechanisms of glomerulosclerosis in diabetic nephropathy. Diabetes 2008, 57:1439-1445

8. Galkina E, Ley K: Leukocyte recruitment and vascular injury in diabetic nephropathy. J Am Soc Nephrol 2006, 17:368-377

9. Navarro-Gonzalez JF, Mora-Fernandez C, Muros de Fuentes M, Garcia-Perez J: Inflammatory molecules and pathways in the pathogenesis of diabetic nephropathy. Nat Rev Nephrol 2011, 7:327-340

10. Nguyen D, Ping F, Mu W, Hill P, Atkins RC, Chadban SJ: Macrophage accumulation in human progressive diabetic nephropathy. Nephrology (Carlton) 2006, 11:226-231

11. Tesch GH: Macrophages and diabetic nephropathy. Semin Nephrol 2010, 30:290-301

12. Rothlin CV, Ghosh S, Zuniga EI, Oldstone MB, Lemke G: TAM receptors are pleiotropic inhibitors of the innate immune response. Cell 2007, 131:1124-1136

13. Linger RM, Keating AK, Earp HS, Graham DK: TAM receptor tyrosine kinases: biologic functions, signaling, and potential therapeutic targeting in human cancer. Adv Cancer Res 2008, 100:35-83

14. Lemke G, Rothlin CV: Immunobiology of the TAM receptors. Nat Rev Immunol 2008, 8:327-336

15. Lemke G, Burstyn-Cohen T: TAM receptors and the clearance of apoptotic cells. Ann N Y Acad Sci 2010, 1209:23-29

16. Lemke G, Lu Q: Macrophage regulation by Tyro 3 family receptors. Curr Opin Immunol 2003, 15:31-36

17. Lu Q, Lemke G: Homeostatic regulation of the immune system by receptor tyrosine kinases of the Tyro 3 family. Science 2001, 293:306-311

18. Rothlin CV, Lemke G: TAM receptor signaling and autoimmune disease. Curr Opin Immunol 2010, 22:740-746
19. Hafizi S, Dahlback B: Gas6 and protein S. Vitamin K-dependent ligands for the Axl receptor tyrosine kinase subfamily. FEBS J 2006, 273:5231-5244

20. Stitt TN, Conn G, Gore M, Lai C, Bruno J, Radziejewski C, Mattsson K, Fisher J, Gies DR, Jones PF, Masiakowski P, Ryan TE, Tobkes NJ, Chen DH, DiStefano PS, Long GL, Basilico C, Goldfarb MP, Lemke G, Glass DJ, Yancopoulos GD: The anticoagulation factor protein S and its relative, Gas6, are ligands for the Tyro 3/Axl family of receptor tyrosine kinases. Cell 1995, 80:661-670

21. Castoldi E, Hackeng TM: Regulation of coagulation by protein S. Curr Opin Hematol 2008, 15:529-536

22. Rezende SM, Simmonds RE, Lane DA: Coagulation, inflammation, and apoptosis: different roles for protein $\mathrm{S}$ and the protein $\mathrm{S}-\mathrm{C} 4 \mathrm{~b}$ binding protein complex. Blood 2004, 103:1192-1201

23. Takagi T, Taguchi O, Aoki S, Toda M, Yamaguchi A, Fujimoto H, Boveda-Ruiz D, Gil-Bernabe P, Ramirez AY, Naito M, Yano Y, D'Alessandro-Gabazza CN, Fujiwara A, Takei Y, Morser J, Gabazza EC: Direct effects of protein S in ameliorating acute lung injury. J Thromb Haemost 2009, 7:2053-2063

24. Zhong Z, Wang Y, Guo H, Sagare A, Fernandez JA, Bell RD, Barrett TM, Griffin JH, Freeman RS, Zlokovic BV: Protein S protects neurons from excitotoxic injury by activating the TAM receptor Tyro3-phosphatidylinositol 3-kinase-Akt pathway through its sex hormone-binding globulin-like region. J Neurosci 2010, 30: $15521-15534$

25. Zhu D, Wang Y, Singh I, Bell RD, Deane R, Zhong Z, Sagare A, Winkler EA, Zlokovic BV: Protein S controls hypoxic/ischemic bloodbrain barrier disruption through the TAM receptor Tyro3 and sphingosine 1-phosphate receptor. Blood 2010, 115:4963-4972

26. Nagai K, Arai H, Yanagita M, Matsubara T, Kanamori H, Nakano T, Iehara N, Fukatsu A, Kita T, Doi T: Growth arrest-specific gene 6 is involved in glomerular hypertrophy in the early stage of diabetic nephropathy. J Biol Chem 2003, 278:18229-18234

27. Yanagita M, Arai H, Ishii K, Nakano T, Ohashi K, Mizuno K, Varnum B, Fukatsu A, Doi T, Kita T: Gas6 regulates mesangial cell proliferation through Axl in experimental glomerulonephritis. Am J Pathol 2001, 158:1423-1432

28. Budagian V, Bulanova E, Orinska Z, Duitman E, Brandt K, Ludwig A, Hartmann D, Lemke G, Saftig P, Bulfone-Paus S: Soluble Axl is generated by ADAM10-dependent cleavage and associates with Gas6 in mouse serum. Mol Cell Biol 2005, 25:9324-9339

29. Thorp E, Vaisar T, Subramanian M, Mautner L, Blobel C, Tabas I: Shedding of the Mer tyrosine kinase receptor is mediated by ADAM17 protein through a pathway involving reactive oxygen species, protein kinase Cdelta, and p38 mitogen-activated protein kinase (MAPK). J Biol Chem 2011, 286:33335-33344

30. Wu J, Ekman C, Jonsen A, Sturfelt G, Bengtsson AA, Gottsater A, Lindblad B, Lindqvist E, Saxne T, Dahlback B: Increased plasma levels of the soluble Mer tyrosine kinase receptor in systemic lupus erythematosus relate to disease activity and nephritis. Arthritis Res Ther 2011, 13:R62

31. Sather S, Kenyon KD, Lefkowitz JB, Liang X, Varnum BC, Henson PM, Graham DK: A soluble form of the Mer receptor tyrosine kinase inhibits macrophage clearance of apoptotic cells and platelet aggregation. Blood 2007, 109:1026-1033

32. Lee IJ, Hilliard BA, Ulas M, Yu D, Vangala C, Rao S, Lee J, Gadegbeku CA, Cohen PL: Monocyte and plasma expression of TAM ligand and receptor in renal failure: links to unregulated immunity and chronic inflammation. Clin Immunol 2015, 158: 231-241

33. Ahdi M, Gerdes VE, Graaff R, Kuipers S, Smit AJ, Meesters EW: Skin autofluorescence and complications of diabetes: does ethnic background or skin color matter? Diabetes Technol Ther 2015, 17: 88-95

34. Schnog JB, Mac Gillavry MR, van Zanten AP, Meijers JC, Rojer RA, Duits AJ, ten Cate H, Brandjes DP: Protein C and S and inflammation in sickle cell disease. Am J Hematol 2004, 76:26-32 
35. Lattenist L, Ochodnický P, Ahdi M, Claessen N, Leemans JC, Satchell SC, Florquin S, Gerdes VE, Roelofs JJ: Renal endothelial protein $\mathrm{C}$ receptor expression and shedding during diabetic nephropathy. J Thromb Haemost 2016, 14:1171-1182

36. Strober W: Trypan blue exclusion test of cell viability. Curr Protoc Immunol 2001, Appendix 3. Appendix 3B

37. Recarte-Pelz P, Tassies D, Espinosa G, Hurtado B, Sala N, Cervera R, Reverter JC, de Frutos PG: Vitamin K-dependent proteins GAS6 and Protein $\mathrm{S}$ and TAM receptors in patients of systemic lupus erythematosus: correlation with common genetic variants and disease activity. Arthritis Res Ther 2013, 15:R41

38. Zizzo G, Guerrieri J, Dittman LM, Merrill JT, Cohen PL: Circulating levels of soluble MER in lupus reflect M2c activation of monocytes/macrophages, autoantibody specificities and disease activity. Arthritis Res Ther 2013, 15:R212

39. Pickup JC: Inflammation and activated innate immunity in the pathogenesis of type 2 diabetes. Diabetes Care 2004, 27:813-823

40. Fraineau S, Monvoisin A, Clarhaut J, Talbot J, Simonneau C, Kanthou C, Kanse SM, Philippe M, Benzakour O: The vitamin Kdependent anticoagulant factor, protein S, inhibits multiple VEGF-A- induced angiogenesis events in a Mer- and SHP2-dependent manner. Blood 2012, 120:5073-5083

41. Gould WR, Baxi SM, Schroeder R, Peng YW, Leadley RJ, Peterson JT, Perrin LA: Gas6 receptors Axl, Sky and Mer enhance platelet activation and regulate thrombotic responses. J Thromb Haemost 2005, 3:733-741

42. Deng T, Zhang Y, Chen Q, Yan K, Han D: Toll-like receptor-mediated inhibition of Gas6 and ProS expression facilitates inflammatory cytokine production in mouse macrophages. Immunology 2012, 135:40-50

43. Lee IJ, Hilliard B, Swami A, Madara JC, Rao S, Patel T, Gaughan JP, Lee J, Gadegbeku CA, Choi ET, Cohen PL: Growth arrest-specific gene 6 (Gas6) levels are elevated in patients with chronic renal failure. Nephrol Dial Transplant 2012, 27:4166-4172

44. Nagai K, Matsubara T, Mima A, Sumi E, Kanamori H, Iehara N, Fukatsu A, Yanagita M, Nakano T, Ishimoto Y, Kita T, Doi T, Arai H: Gas6 induces Akt/mTOR-mediated mesangial hypertrophy in diabetic nephropathy. Kidney Int 2005, 68:552-561

45. Collett GD, Sage AP, Kirton JP, Alexander MY, Gilmore AP, Canfield AE: Axl/phosphatidylinositol 3-kinase signaling inhibits mineral deposition by vascular smooth muscle cells. Circ Res 2007, 100:502-509 